\title{
LEAF GAS EXCHANGE AND FLOWERING OF MANGO SPRAYED WITH BIOSTIMULANT IN SEMI-ARID REGION ${ }^{1}$
}

\author{
LAIANE EUGÊNIA DELMONDES MUDO ${ }^{2 *}$, JACKSON TEIXEIRA LOBO ${ }^{3}$, DANIEL DE ALMEIDA CARREIRO2 \\ JEFERSON ANTÔNIO CAVACINI ${ }^{2}$, LUAN DOS SANTOS SILVA ${ }^{4}$, ÍTALO HERBERT LUCENA CAVALCANTE ${ }^{2}$
}

\begin{abstract}
The aim of the present study was to evaluate the effect of biostimulant containing amino acids and yeast extract on the physiological and reproductive characteristics of mango cv. Tommy Atkins during the shoot maturation phase in tropical semi-arid region. The experimental design consisted of randomized blocks with five treatments, five replications and five plants per plot. Treatments consisted of: T1) two foliar sprays with [biostimulant $+\mathrm{KCl}$ ] + two foliar sprays with $\mathrm{K}_{2} \mathrm{SO}_{4}$; T2) No biostimulant and four foliar sprays with $\mathrm{K}_{2} \mathrm{SO}_{4}$; T3) three individual foliar sprays with biostimulant and one foliar spray with $\mathrm{K}_{2} \mathrm{SO}_{4}$; T4) two foliar sprays with biostimulant and two foliar sprays with $\mathrm{K}_{2} \mathrm{SO}_{4}$; and T5) two foliar sprays with [biostimulant + $\left.\mathrm{K}_{2} \mathrm{SO}_{4}\right]+$ one foliar spray with $\mathrm{K}_{2} \mathrm{SO}_{4}$. There is a positive effect of the biostimulant containing amino acids and yeast extract on transpiration, internal $\mathrm{CO}_{2}$ concentration, water-use efficiency and number of reproductive and non-differentiated shoots of mango cv. Tommy Atkins cultivated under tropical semi-arid condition, with attenuating effect on plant abiotic stress. For shoot maturation of mango cv. Tommy Atkins, three foliar sprays with biostimulant containing amino acids and yeast extract $\left(10 \mathrm{~mL}\right.$ per plant) and one with $\mathrm{K}_{2} \mathrm{SO}_{4}(3 \%)$, starting at 45 days after paclobutrazol application (T3), can be recommended.
\end{abstract}

Keywords: Mangifera indica L. Abiotic stress. Shoot maturation. Production system.

\section{TROCAS GASOSAS FOLIARES E FLORESCIMENTO DE MANGUEIRA PULVERIZADA COM BIOESTIMULANTE NA REGIÃO DO SEMIÁRIDO}

RESUMO - O objetivo com este estudo foi avaliar efeito de bioestimulante contendo aminoácidos e extrato de levedura nas respostas fisiológicas e reprodutivas de mangueiras cv. Tommy Atkins durante a fase de maturação de ramos, em condição semiárida tropical. O delineamento experimental foi em blocos ao acaso, com cinco tratamentos, cinco repetições e cinco plantas por parcela. Os tratamentos foram: T1) Duas pulverizações com bioestimulante $+\mathrm{KCl}$ e duas pulverizações com $\mathrm{K}_{2} \mathrm{SO}_{4}$; T2) Quatro pulverizações com $\mathrm{K}_{2} \mathrm{SO}_{4}$ sem bioestimulante; T3) Três pulverizações individuais com bioestimulante e uma pulverização com $\mathrm{K}_{2} \mathrm{SO}_{4}$; T4) Duas pulverizações com bioestimulante e duas pulverizações com $\mathrm{K}_{2} \mathrm{SO}_{4}$; e T5) Duas pulverizações com bioestimulante $+\mathrm{K}_{2} \mathrm{SO}_{4}$ e uma pulverização com $\mathrm{K}_{2} \mathrm{SO}_{4}$. Há efeito positivo do bioestimulante contendo aminoácidos e extrato de levedura na transpiração, concentração interna de $\mathrm{CO}_{2}$, eficiência do uso da água e número de gemas reprodutivas e não-diferenciadas da mangueira cv. Tommy Atkins cultivada em condição semiárida tropical, com efeito atenuador no estresse abiótico vegetal. Para a maturação de ramos de mangueira cv. Tommy Atkins pode-se recomendar três pulverizações foliares de bioestimulante contendo aminoácidos e extrato de levedura (10 mL por planta) e uma de $\mathrm{K}_{2} \mathrm{SO}_{4}(3 \%)$, iniciando aos 45 dias após aplicação de paclobutrazol (T3).

Palavras-chave: Mangifera indica L. Estresse abiótico. Maturação de ramos. Sistema de produção. 


\section{INTRODUCTION}

Brazil is the seventh largest producer of mango, with an annual production of 1.087 million tons, in 64.463 hectares of cultivated area, with an average yield of $17.012 \mathrm{t} \mathrm{ha}^{-1}$ (FAO, 2017). São Francisco Valley (semi-arid climate) is the main production center, responsible for $89 \%$ of Brazilian exports (AGROSTAT/MAPA, 2018), especially for the cultivar Tommy Atkins (ARAÚJO; MORAES; CARVALHO, 2017).

In Northeast Brazil, the semi-arid climate is predominant, characterized by high temperatures and low air humidity. Under such conditions, the flowering management of mango (Mangifera indica L.), a complex process affected by genetic, environmental, hormonal and nutritional factors (TIWARI; PATEL; PANDEY, 2018), involves a set of agronomical practices such as pruning, plant growth regulators, water stress and shoot maturation (DAVENPORT, 2003; CAVALCANTE et al., 2018). It must be pointed out that in mango trees, high temperatures not only inhibit the vegetative growth, but also cause considerable reduction in photosynthetic rates (LAXMAN; ANNAPOORNAMMA; BIRADAR, 2016).

The shoot maturation phase, which precedes floral induction, is crucial to obtain uniform flowerings especially in the tropical semi-arid region (CAVALCANTE et al., 2018). At this stage, irrigation should be reduced to below the crop needs to stimulate the synthesis of ethylene, the hormone responsible for improving mango flowering (DAVENPORT, 2006), as well as foliar applications, especially with potassium and sulfur, considering that the former affects photosynthesis, respiration and translocation of solutes (HAWKESFORD et al., 2012) and the latter is required during the Yang cycle to promote ethylene biosynthesis (TAIZ et al., 2017). As a result of this management and the local conditions with high temperatures and low air humidity, plants are constantly under stress (SANTOS et al., 2016).

An alternative to mitigate abiotic stresses in plants has been the use of biostimulants (DU JARDIN, 2015), which are biological substances capable of improving the nutritional efficiency, yield and quality of agricultural products (YAKHIN et al., 2017). Moreover, the reduction of the stress caused by drought was associated with the use of biostimulants containing amino acids and yeast extract (HAMMAD; ALI, 2014), because amino acids influence plant physiological activities, while the yeast extract works as a natural source of cytokinin and beneficial substances, such as vitamins B1, B2, B3 and B12 and organic compounds, proteins, carbohydrates, nucleic acid and lipids (ABD EL-MOTTY et al., 2010).

In a study conducted with the mango cv. Palmer in Brazilian semi-arid region, Cavalcante et al. (2018) recorded beneficial effects on shoot maturation when using biostimulant containing free amino acids and Ascophyllum nodosum seaweed extract; however, the physiological responses depends on mango cultivar and on the composition of the biostimulant used.

Therefore, this study was conducted aiming to evaluate the effect of biostimulant containing amino acids and yeast extract on the physiological and reproductive characteristics of mango cv. Tommy Atkins during the shoot maturation phase in tropical semi-arid region.

\section{MATERIAL AND METHODS}

Mango cv. Tommy Atkins with uniform crown size and vigor, and twenty years of age, was used in this study. The experiment was carried out in 2017 and 2018 in an orchard located on the Barreiro de Santa Fé farm, municipality of Casa Nova $\left(9^{\circ}\right.$ $23^{\prime} \mathrm{S}$ and $40^{\circ} 43^{\prime} \mathrm{W}$, altitude of 402 above sea level), Bahia state, Brazil. The climate of the region is classified as Bsh, characterized as semi-arid with an annual rainfall average below $500 \mathrm{~mm}$ (ALVARES et al., 2013). During the execution of the experiment (from August to February), the meteorological data were monitored by an automatic weather station, which recorded the highest and lowest air temperatures of 38.76 and $16.36{ }^{\circ} \mathrm{C}$, respectively, with an average of $27.56{ }^{\circ} \mathrm{C}$; the average air humidity was $52.81 \%$.

The plants, at spacing of $10.0 \mathrm{~m}$ between rows and $5.0 \mathrm{~m}$ between plants, were submitted to daily irrigation by micro sprinkler, with two emitters per plant and a flow rate of approximately $40 \mathrm{~L} \mathrm{~h}^{-1}$ each. Management practices such as weed and phytosanitary control, use of the growth regulator paclobutrazol (PBZ) (28.1 mL per plant of Cultar ${ }^{\circledR}$ ), and dormancy break (potassium nitrate and calcium nitrate at $3.0 \%$ ) were carried out every seven days, as recommended by Albuquerque, Medina and Mouco (2002), while fertilizing management was carried out via fertigation according to plant demand (SILVA et al., 2002; BARBOSA; CAVALCANTE; LIMA, 2016). The production pruning was carried out mechanically, while manual tip pruning was performed to synchronize the vegetative canopy flushes.

Before shoot maturation began, foliar samples were collected to determine the nutritional status of the plants used. Mature leaves of the last vegetative flush of the shoots located in the central part of the plant canopy were collected to determine macro and micronutrient contents (Table 1). After that, the leaves were washed with distilled water and dried at $65{ }^{\circ} \mathrm{C}$ until reaching a constant weight and posteriorly chemically analyzed following the method of Malavolta, Vitti and Oliveira (1997). 
L. E. D. MUDO et al.

Table 1. Leaf nutrient concentrations of the mango orchard cv. Tommy Atkins before the experiment.

\begin{tabular}{|c|c|c|c|c|c|c|c|c|}
\hline $\mathrm{N}$ & $\mathrm{P}$ & K & $\mathrm{Ca}$ & $\mathrm{Mg}$ & $\mathrm{Mn}$ & & $\mathrm{Zn}$ & $\mathrm{B}$ \\
\hline \multicolumn{5}{|c|}{$\mathrm{g} \mathrm{kg}^{-1}$} & \multicolumn{4}{|c|}{$-\mathrm{mg} \mathrm{kg}^{-1}$} \\
\hline & 1.54 & 12.75 & 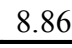 & & 57 & 31.02 & 76.11 & 8. \\
\hline
\end{tabular}

The experimental design was randomized blocks with five treatments, five replications and five plants per plot. The treatments adopted were defined according to plant demands and physiological changes that occur during shoot maturation, which precedes the floral induction in the production system adopted in the São Francisco Valley, as described by Albuquerque, Medina and Mouco (2002). Therefore, the treatments were formed by combinations of a biostimulant and potassium, consisting of: T1) Two foliar sprays with biostimulant $(10 \mathrm{~mL}$ per plant $)+\mathrm{KCl}(120 \mathrm{mg}$ per plant, $60 \% \mathrm{~K}_{2} \mathrm{O}$ ) and two foliar sprays with $\mathrm{K}_{2} \mathrm{SO}_{4}$ (120 mg per plant, $50 \% \mathrm{~K}_{2} \mathrm{O}$ ); T2) four foliar sprays with $\mathrm{K}_{2} \mathrm{SO}_{4}$ without biostimulant; T3) three foliar sprays with biostimulant $(10 \mathrm{~mL}$ per plant) and one foliar spray with $\mathrm{K}_{2} \mathrm{SO}_{4}(120 \mathrm{mg}$ per plant, $50 \%$ $\mathrm{K}_{2} \mathrm{O}$ ); T4) two foliar sprays with biostimulant (10 $\mathrm{mL}$ per plant) and two foliar sprays with $\mathrm{K}_{2} \mathrm{SO}_{4}(120$ mg per plant, $50 \% \mathrm{~K}_{2} \mathrm{O}$ ); and $\left.\mathrm{T} 5\right)$ two foliar sprays of biostimulant $\left(10 \mathrm{~mL}\right.$ per plant) with $\mathrm{K}_{2} \mathrm{SO}_{4}(120$ $\mathrm{mg}$ per plant, $\left.50 \% \mathrm{~K}_{2} \mathrm{O}\right)$ and one more foliar spray of $\mathrm{K}_{2} \mathrm{SO}_{4}\left(120 \mathrm{mg}\right.$ per plant, $50 \% \mathrm{~K}_{2} \mathrm{O}$ ).

The biostimulant utilized was the Bulk $\left(\right.$ Alltech $\left.{ }^{\circledR}\right)$, composed of water-soluble K $(12 \%$ de $\mathrm{KCl})$, organic carbon $(9.87 \%)$, amino acids $(20 \%)$, anionic surfactants and yeast extract. Treatments application was based on the number of days after the application of gibberellin inhibitor, paclobutrazol (PBZ) ([(2RS, 3RS)-1- (4-chlorophenyl)-4,4dimethyl-2-(1H-1,2,4-triazol-1-il) pentan-3-ol]), with intervals of ten days between each application, beginning at 45 days after PBZ (T3) and 60 days after PBZ (T1, T2, T4 and T5), based on the commercial management adopted in the São Francisco Valley, corresponding to control treatment (T2). The determination of quantity of days after PBZ for T3 was performed following the recommendations of Cavalcante et al. (2018).

During the pre-flowering (130 days after PBZ application) and full-flowering (157 days after PBZ application), the following parameters were evaluated: i) net photosynthesis $-A\left(\mu \mathrm{mol}\right.$ of $\mathrm{CO}_{2} \mathrm{~m}^{-}$ $\left.2 \mathrm{~s}^{-1}\right)$; ii) stomatal conductance $-g s\left(\mathrm{~mol}\right.$ of $\mathrm{H}_{2} \mathrm{O} \mathrm{m} \mathrm{m}^{-2}$ $\left.\mathrm{s}^{-1}\right)$; iii) transpiration $-E\left(\mathrm{mmol}\right.$ of $\left.\mathrm{H}_{2} \mathrm{O} \mathrm{m}^{2} \mathrm{~s}^{-1}\right)$; iv) internal $\mathrm{CO}_{2}$ concentration $-\mathrm{Ci}\left(\mathrm{mmol}\right.$ of $\mathrm{CO}_{2} \mathrm{~m}^{-2} \mathrm{~s}^{-}$ $\left.{ }^{1}\right)$; v) water-use efficiency (WUE) ( $\mu \mathrm{mol}$ of $\mathrm{CO}_{2} /$ mmol of $\mathrm{H}_{2} \mathrm{O}$ ) calculated as the ratio between net photosynthesis and transpiration, through an infrared gas analyzer (IRGA) (Mod. Li-COR ${ }^{\circledR} 6400$ XT). The evaluations were carried out with mature leaves between 9:00 and 11:00 am.

The water amount at the pre-flowering phase corresponded to $50 \%$ of crop evapotranspiration
(ETc) and, at the full-flowering phase it corresponded to $100 \%$ of ETc.

At the bud differentiation phase (142 days after PBZ application, for all treatments), the reproductive and non-differentiated (quiescent, vegetative and mixed) buds were quantified within a $1 \mathrm{~m}^{2}$ quadrate made with polyvinyl chloride pipe, placed randomly on east and west sides in each tree (RAMÍREZ et al., 2010); at the full-flowering stage, the proportions of staminate and monocline flowers from two panicles a plant, collected from east and west sides of three plants per repetition, were determined.

The data of all variables were submitted to analysis of variance (ANOVA) and posteriorly to Tukey's multiple comparison test $(\mathrm{p}<0.05)$. Statistical analyses were performed using the SISVAR software (FERREIRA, 2011).

\section{RESULTS AND DISCUSSION}

For net photosynthesis $(A)$ and stomatal conductance $(g s)$, no difference was recorded among the shoot maturation strategies evaluated at the preflowering and full-flowering stages, although the internal $\mathrm{CO}_{2}$ concentration $\left(C_{i}\right)$, transpiration $(E)$ and water-use efficiency ( $W U E$ ) were affected by the biostimulant during the pre-flowering phase (Table 2).

The average result for net photosynthesis during pre-flowering was $4.076 \mu \mathrm{mol}$ of $\mathrm{CO}_{2} \mathrm{~m}^{-2} \mathrm{~s}^{-1}$ and, at the full-flowering, it was $9.476 \mu \mathrm{mol}$ of $\mathrm{CO}_{2} \mathrm{~m}^{-2} \mathrm{~s}^{-1}$ (Table 2). It must be emphasized that the difference recorded between the phases occurred not only due to the mango phenological changes, but also due to different water managements carried out in each evaluated period; at pre-flowering the plants were submitted to water stress, even if moderately (reduction of $50 \%$ of initial water amount), a technique recommended for mango floral induction management in semi-arid region (ALBUQUERQUE; MEDINA; MOUCO, 2002), while at the fullflowering phase the irrigation was normally applied according to crop demand.

The increment in photosynthesis values from pre-flowering to full-flowering contradicts the results found in the scientific literature, since according to Urban et al. (2008) leaf photosynthesis tends to be negatively affected by the flowering process. However, the same authors mention the difficulty in establishing a photosynthetic pattern in plants submitted to water stress conditions even if it is not severe, a strategy commonly performed in 
floral induction process of mango production in semi -arid regions. In the present experiment, it can be seen that the reduction of water amount negatively affected the photosynthetic metabolism of mango trees, which is in agreement with Taiz et al. (2017), and indicates a different photosynthetic pattern for mango under tropical semi-arid conditions due to the management adopted in this crop production system.

Table 2. Net photosynthesis $(A)$, stomatal conductance $(g s)$, internal $\mathrm{CO}_{2}$ concentration $\left(C_{i}\right)$, transpiration $(E)$ and water-use efficiency $(W U E)$ in mango cv. Tommy Atkins as a function of shoot maturation management.

\begin{tabular}{|c|c|c|c|c|c|}
\hline SV & $\begin{array}{c}A \\
\mu \mathrm{mol} \text { of } \mathrm{CO}_{2} \mathrm{~m}^{-2} \mathrm{~s}^{-1}\end{array}$ & mol of $\underset{\mathrm{s}^{-1}}{g S}$ & $\underset{\mathrm{mmol} \text { of } \underset{1}{\mathrm{C} \mathrm{O}_{2}} \mathrm{~m}^{-2} \mathrm{~s}^{-}}{ }$ & $\begin{array}{c}E \\
\text { mmol of } \mathrm{H}_{2} \mathrm{O} \mathrm{m}^{2} \mathrm{~s}^{-1}\end{array}$ & $\begin{array}{c}\text { WUE } \\
\mu \mathrm{mol} \text { of } \\
\mathrm{CO}_{2} / \mathrm{mmol} \text { of } \\
\mathrm{H}_{2} \mathrm{O}\end{array}$ \\
\hline & \multicolumn{5}{|c|}{ Pre-flowering } \\
\hline Value 'F' & $0.7177^{\mathrm{ns}}$ & $0.0633^{\text {ns }}$ & $0.0003^{*}$ & $0.0069^{*}$ & $0.0001^{* *}$ \\
\hline$\overline{\mathrm{T} 1}-$ & $-\overline{3.42}-$ & $\overline{0.0} \overline{2}$ & $\overline{90} . \overline{0} 8 \mathrm{c}$ & $-\overline{0.70 \mathrm{c}}$ & $\overline{4} . \overline{8} 9 \mathrm{a}$ \\
\hline $\mathrm{T} 2$ & 3.78 & 0.02 & $103.69 b c$ & $0.75 b c$ & $5.04 \mathrm{a}$ \\
\hline $\mathrm{T} 3$ & 4.34 & 0.03 & $117.76 b c$ & 1.19 & $3.65 \mathrm{~b}$ \\
\hline $\mathrm{T} 4$ & 4.58 & 0.04 & $169.04 \mathrm{ab}$ & $1.59 \mathrm{ab}$ & $2.88 \mathrm{bc}$ \\
\hline $\mathrm{T} 5$ & 4.26 & 0.04 & 190.11a & $1.71 \mathrm{a}$ & $2.49 \mathrm{c}$ \\
\hline \multirow[t]{2}{*}{$\bar{C} \bar{V}(\overline{\%})$} & $\overline{3} \overline{7} . \overline{8}$ & $\overline{37.95}$ & $\overline{24} \overline{4} \overline{6}$ & $\overline{36.83}$ & $\overline{14.32}$ \\
\hline & \multicolumn{5}{|c|}{$\begin{array}{l}\text { Full-flowering } \\
\end{array}$} \\
\hline Value 'F' & $0.4842^{\mathrm{ns}}$ & $0.3978^{\text {ns }}$ & $0.1234^{\mathrm{ns}}$ & $0.3050^{\text {ns }}$ & $-0.07^{\mathrm{ns}}$ \\
\hline$\overline{\mathrm{T}} 1$ & $-\overline{7.93}-$ & $-\overline{0.0} \overline{6}-$ & $-1 \overline{4} 8 . \overline{85}$ & $-\overline{2} . \overline{4} 8^{--}$ & $-\overline{3.20}-$ \\
\hline $\mathrm{T} 2$ & 12.02 & 0.11 & 165.74 & 3.76 & 3.20 \\
\hline $\mathrm{T} 3$ & 8.21 & 0.07 & 152.62 & 2.61 & 3.15 \\
\hline $\mathrm{T} 4$ & 9.88 & 0.10 & 186.39 & 3.58 & 2.76 \\
\hline$-\frac{T 5}{C V}(\%)$ & $\frac{9.34}{30 . \overline{4}-}$ & $-\frac{0.09}{37.8 \overline{2}}$ & $-\frac{193.04}{17.64}-$ & $--\frac{3.42}{30.09}-$ & $-\frac{2.73}{12.87}=-$ \\
\hline
\end{tabular}

SV: Sources of variation. Means followed by the same lower-case letter in the column do not differ from each other by the Tukey test at $5 \%$ probability; **: significant $(\mathrm{p}<0.01)$; *: significant $(\mathrm{p}<0.05)$; ns: not significant; CV\%: coefficient of variation. T1: two foliar sprays with (biostimulant $+\mathrm{KCl}$ ) + two foliar sprays with $\mathrm{K}_{2} \mathrm{SO}_{4}$; $\mathrm{T} 2$ : no biostimulant and four foliar sprays with $\mathrm{K}_{2} \mathrm{SO}_{4}$; T3: three individual foliar sprays with biostimulant and one individual foliar spray with $\mathrm{K}_{2} \mathrm{SO}_{4}$; T4: two individual foliar sprays with biostimulant and two individual foliar sprays with $\mathrm{K}_{2} \mathrm{SO}_{4}$; and T5: two foliar sprays with (biostimulant $+\mathrm{K}_{2} \mathrm{SO}_{4}$ ) + one individual foliar sprays with $\mathrm{K}_{2} \mathrm{SO}_{4}$.

Stomatal conductance averages were 0.03 and $0.09 \mathrm{~mol} \mathrm{~m}^{-2} \mathrm{~s}^{-1}$ at the pre-flowering and fullflowering, respectively (Table 2). When the plant is put under stresses, the tendency is that the stomata close and, as a result, there is a reduction of transpiration to achieve a minimal loss of the water contained in the plant (SILVA et al., 2019). In addition, Schaffer et al. (2009) infer that stomatal conductance is the main factor to control the net photosynthesis in mango trees, including with linear and exponential relations between these variables, due to a decrease in $\mathrm{CO}_{2}$ supply to the mesophyll cells caused by stomatal closure, resulting in lower net photosynthetic rate (LAXMAN; ANNAPOORNAMMA; BIRADAR, 2016). In this context, the present study shows that the treatments that promoted the highest stomatal conductance also led to highest net photosynthesis (Table 2).

$\mathrm{Lu}$ et al. (2012), when evaluating the net photosynthesis and stomatal conductance of five mango cultivars, including 'Tommy Atkins' cultivated in northern Australia, found reduction for both variables in the dry season and maximum responses during the rainy season, conditions that can be compared to the two phases in which the analyses of this work were carried out, and agree with the results contained in (Table 2).
For internal $\mathrm{CO}_{2}$ concentration during preflowering (Figure 1A), T5 was similar to T4 and superior to the other treatments, while $\mathrm{T} 1$ obtained the lowest result, not differing from $\mathrm{T} 2$ and $\mathrm{T} 3$; the difference between T1 and T5 was $100.03 \mathrm{mmol} \mathrm{m}^{-2}$ $\mathrm{s}^{-1}$. In general, the values found in this study are lower than those reported by Santos, Martinez and Donato (2013), in 'Tommy Atkins' mango grown in semi-arid region, which had maximum values of 210 mmol m $\mathrm{m}^{-2} \mathrm{~s}^{-1}$. The high internal $\mathrm{CO}_{2}$ concentration in leaves tend to favor the photosynthesis process (TAIZ et al., 2017); however, no relation was identified between the studied variables in this experiment, a behavior similar to that observed by Vieccelli et al. (2018) in 'Tommy Atkins' mango grown in Minas Gerais State, Brazil.

For transpiration $(E)$ at pre-flowering stage, T5 reached the highest rate $(1.71 \mathrm{mmol}$ de $\mathrm{H}_{2} \mathrm{O} \mathrm{m}^{2} \mathrm{~s}^{-1}$ ), $144 \%$ superior to that of $\mathrm{T} 1$, which was the lowest value recorded (Figure 1B). The results recorded for $\mathrm{T} 3, \mathrm{~T} 4$ and $\mathrm{T} 5$ are similar to those reported by Faria et al. (2016) in a study carried out with mango cv. Tommy Atkins in semi-arid region, a range of 1.23-2.87 mmol of $\mathrm{H}_{2} \mathrm{O} \mathrm{m} \mathrm{m}^{2} \mathrm{~s}^{-1}$, as a function of irrigation management, and also similar to the results reported by Rymbai et al. (2014), who evaluated the physiological indexes of mango 
cultivars in different agroclimatic regions of India and recorded values between 1.19 and $2.43 \mathrm{mmol}$ of $\mathrm{H}_{2} \mathrm{O} \mathrm{m} \mathrm{m}^{-1}$. Under higher transpiration levels, as verified for T3, T4 and T5, plants tend to accumulate
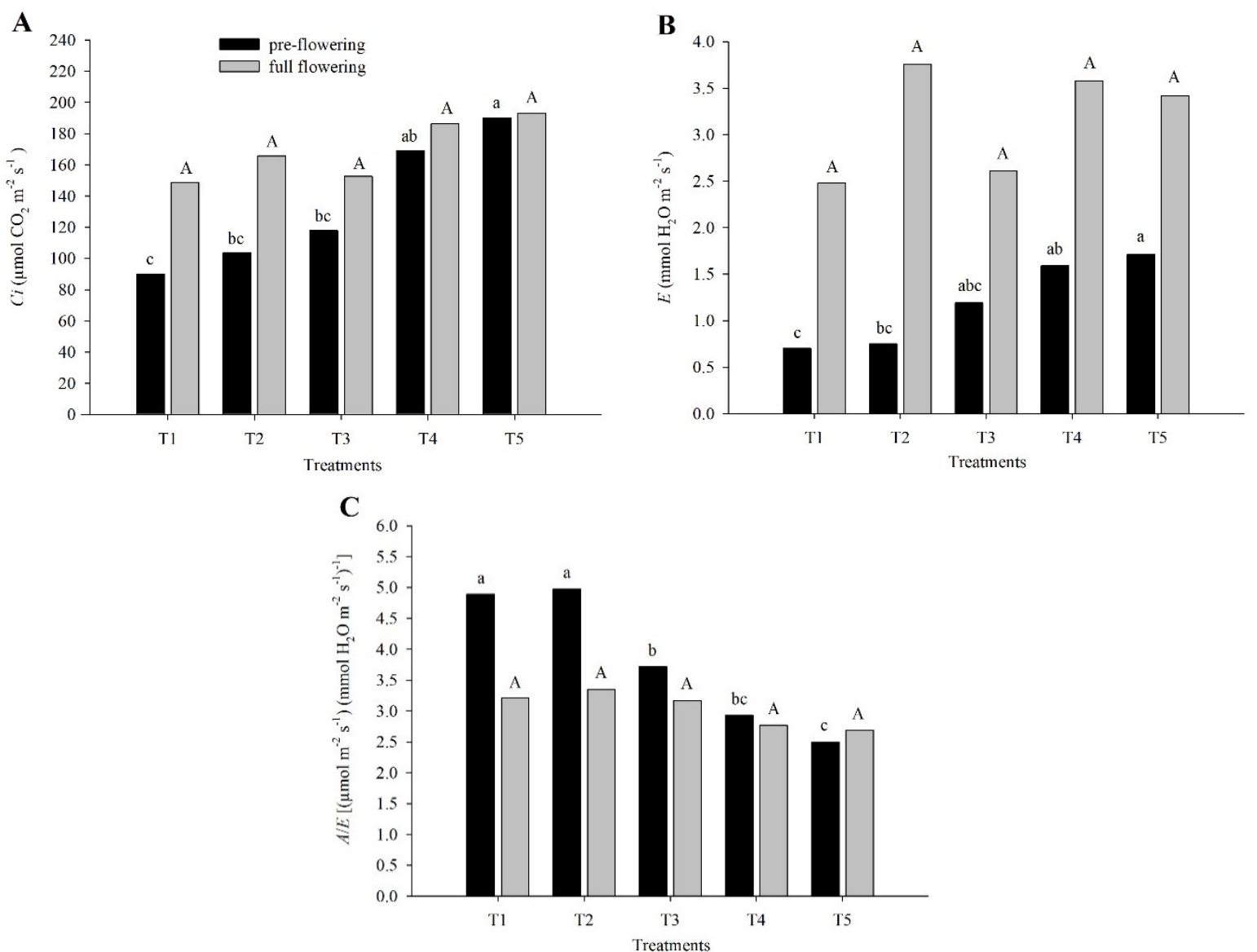

Figure 1. Internal $\mathrm{CO}_{2}$ concentration $-C i(\mathrm{~A})$, transpiration $-E(\mathrm{~B})$ and water-use efficiency $-A / E(\mathrm{C})$ of mango $\mathrm{cv}$. Tommy Atkins evaluated at pre-flowering and full-flowering as a function of shoot maturation management.

Bars with same color and letter do not differ by Tukey's test $(\mathrm{p}<0.05)$. T1: two foliar sprays with (biostimulant $+\mathrm{KCl})+$ two foliar sprays with $\mathrm{K}_{2} \mathrm{SO}_{4}$; T2: no biostimulant and four foliar sprays with $\mathrm{K}_{2} \mathrm{SO}_{4}$; T3: three individual foliar sprays with biostimulant and one individual foliar spray with $\mathrm{K}_{2} \mathrm{SO}_{4}$; $\mathrm{T} 4$ : two individual foliar sprays with biostimulant and two individual foliar sprays with $\mathrm{K}_{2} \mathrm{SO}_{4}$; and T5: two foliar sprays with (biostimulant $+\mathrm{K}_{2} \mathrm{SO}_{4}$ ) + one individual foliar sprays with $\mathrm{K}_{2} \mathrm{SO}_{4}$.

Regarding the water-use efficiency during the pre-flowering, $\mathrm{T} 1$ and $\mathrm{T} 2 \mathrm{had}$ the highest results, while T5 was the less efficient treatment (Figure 1C). Faria et al. (2016) recorded a variation from 0.92 to $4.35 \mu \mathrm{mol}$ of $\mathrm{CO}_{2} / \mathrm{mmol}$ of $\mathrm{H}_{2} \mathrm{O}$ in mango cv. Tommy Atkins growing in semi-arid environment, a broader range than the one recorded in this study where the results, even those found at the fullflowering, reached a mean of $3.17 \mathrm{mmol} \mathrm{H}_{2} \mathrm{O} \mathrm{L}^{-1}$.

Silva, Campos and Azevedo (2009) reported that mango trees under low water availability showed the highest water-use efficiency. Thus, under the conditions of the present study, although the responses were lower for this variable, it is highlighted that $\mathrm{T} 4$ and $\mathrm{T} 5$ promoted a better water maintenance in the plants. The fact that $\mathrm{T} 1$ and $\mathrm{T} 2$ promoted superior results is probably attributed to the higher $\mathrm{K}^{+}$amount in such treatments, because this ion acts positively on cell osmotic regulation (HAWKESFORD et al., 2012).

Through empirical knowledge (data not published), photosynthesis is expected to affect shoot maturation in mango due to the supply of photoassimilates; however, the scientific literature does not have studies associating variables such as internal $\mathrm{CO}_{2}$ concentration, transpiration and wateruse efficiency with the physiological shoot maturation in mango trees. In this study, it can be seen that greater internal $\mathrm{CO}_{2}$ concentration (Figure $1 \mathrm{~A}$ ), greater transpiration (Figure 1B), and lower water-use efficiency (Figure 1C) at the pre-flowering phase can be associated with a greater number of reproductive shoots produced (panicles) (Figure 2). 


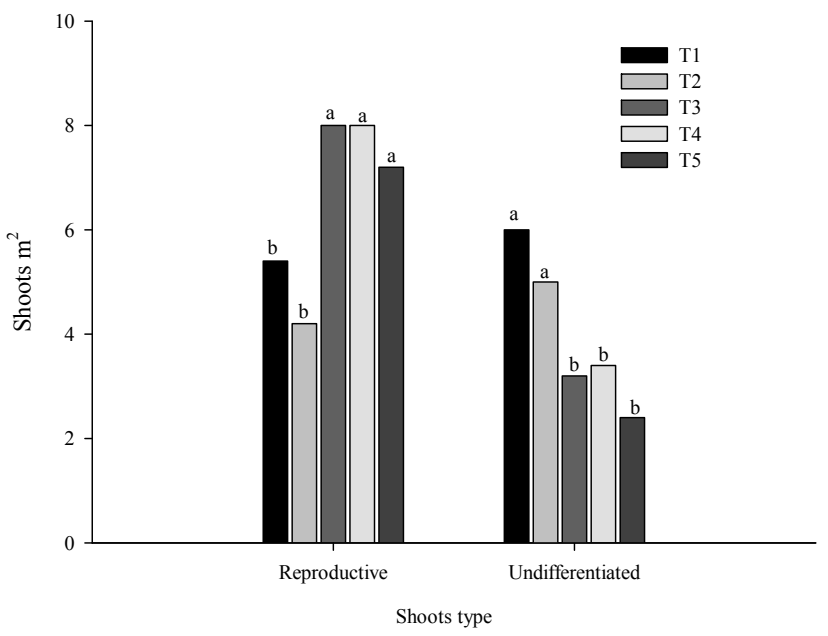

Figure 2. Number of reproductive and non-differentiated shoots per $\mathrm{m}^{2}$ in mango cv. Tommy Atkins as a function of shoot maturation management.

Bars followed by the same letter do not differ by Tukey's test $(\mathrm{p}<0.05)$ to the same type of branch. T1: two foliar sprays with (biostimulant $+\mathrm{KCl}$ ) + two foliar sprays with $\mathrm{K}_{2} \mathrm{SO}_{4}$; T2: no biostimulant and four foliar sprays with $\mathrm{K}_{2} \mathrm{SO}_{4}$; $\mathrm{T}_{3}$ : three individual foliar sprays with biostimulant and one individual foliar spray with $\mathrm{K}_{2} \mathrm{SO}_{4}$; $\mathrm{T} 4$ : two individual foliar sprays with biostimulant and two individual foliar sprays with $\mathrm{K}_{2} \mathrm{SO}_{4}$; and T5: two foliar sprays with (biostimulant $+\mathrm{K}_{2} \mathrm{SO}_{4}$ ) + one individual foliar sprays with $\mathrm{K}_{2} \mathrm{SO}_{4}$.

In general, according to the physiological variables evaluated, it can be seen that T3, T4 and T5 promoted a greater internal $\mathrm{CO}_{2}$ concentration and also a greater transpiration, probably as a result of the greater stomatal opening when compared to T1 and T2 (Table 2), which had lower results. The activity of leaf stomata in the mango crops shows fast responses to environmental conditions such as $\mathrm{CO}_{2}$ concentration, temperature and water restriction, the last one being the most incisive factor (URBAN; JANNOYER, 2004). Usually, any reduction in stomatal conductance and transpiration associated with water-use efficiency increase tends to decrease plant production capacity (FERRAZ et al., 2012); therefore, based on the results obtained, T3, T4 and T5 positively stood out compared to the other treatments. Similar responses were reported by Cavalcante et al. (2018) when evaluating mango cv. Palmer cultivated in semi-arid region in response to a biostimulant containing Ascophyllum nodosum seaweed extract combined with potassium, which acted on nutritional and carbohydrate contents, and also on fruit production.

In relation to the number of reproductive and non-differentiated shoots, there was a significant effect of the treatments, while there was no significant difference for the proportion of flowers (Table 3).

Table 3. Number of reproductive and non-differentiated shoots per $\mathrm{m}^{2}$ in mango cv. Tommy Atkins as a function of shoot maturation management.

\begin{tabular}{|c|c|c|c|c|}
\hline \multirow[b]{2}{*}{ SV } & \multicolumn{2}{|c|}{ Shoot } & \multicolumn{2}{|c|}{ Proportion of flowers (\%) } \\
\hline & Reproductive & Undifferentiated & Monocle flowers & Staminate flowers \\
\hline \multicolumn{5}{|c|}{ Value 'F' $0.6928^{*}$} \\
\hline \multicolumn{5}{|c|}{ 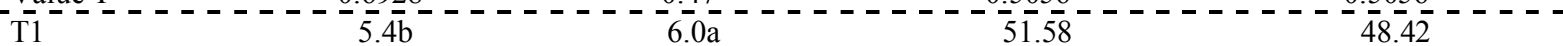 } \\
\hline $\mathrm{T} 2$ & $4.2 b$ & $5.0 \mathrm{a}$ & 45.13 & 54.87 \\
\hline $\mathrm{T} 3$ & $8.0 \mathrm{a}$ & $3.2 b$ & 33.21 & 66.79 \\
\hline & $8.0 \mathrm{a}$ & $3.4 \mathrm{~b}$ & 46.50 & 53.50 \\
\hline & $7.2 \mathrm{a}$ & $2 . \underline{-}-\underline{b}$ & 52.09 & _ \\
\hline & $-\overline{-}-$ & $\overline{8} \overline{4} . \overline{69}$ & $\overline{2} \overline{7} . \overline{13}$ & $\overline{23} . \overline{3} \overline{6}$ \\
\hline
\end{tabular}

SV: Sources of variation. Means followed by the same lower-case letter in the column do not differ from each other by the Tukey test at $5 \%$ probability; **: significant $(\mathrm{p}<0.01)$; *: significant $(\mathrm{p}<0.05)$; ns: not significant; CV\%: coefficient of variation. T1: two foliar sprays with (biostimulant $+\mathrm{KCl}$ ) + two foliar sprays with $\mathrm{K}_{2} \mathrm{SO}_{4}$; $\mathrm{T} 2$ : no biostimulant and four foliar sprays with $\mathrm{K}_{2} \mathrm{SO}_{4}$; T3: three individual foliar sprays with biostimulant and one individual foliar spray with $\mathrm{K}_{2} \mathrm{SO}_{4}$; T4: two individual foliar sprays with biostimulant and two individual foliar sprays with $\mathrm{K}_{2} \mathrm{SO}_{4}$; and $\mathrm{T}$ 5: two foliar sprays with (biostimulant $+\mathrm{K}_{2} \mathrm{SO}_{4}$ ) + one individual foliar sprays with $\mathrm{K}_{2} \mathrm{SO}_{4}$. 
The treatments T3, T4 and T5 led to the best results for the number of reproductive and nondifferentiated shoots with an average of 7.7 reproductive shoots per $\mathrm{m}^{2}$ of crown (Figure 2). It evidences that the same treatments inversely had the lowest responses for the number of non-differenced shoots. In mango tree, the induction of reproductive and vegetative shoots has been conditioned by the proportion between florigenic and vegetative promoters (RAMÍREZ; DAVENPORT, 2010), which consequently is affected by different factors, such as plant and shoots age, nutritional status and climate conditions (TIWARI; PATEL; PANDEY, 2018).

It is important to note that $\mathrm{T} 3$ and $\mathrm{T} 4$ treatments, differently from the others, consist of initial sprays (1st, 2nd and 3rd, and 1st and 2nd, respectively) with biostimulant, which favored the process of reproductive shoot differentiation. The association of biostimulant with $\mathrm{K}_{2} \mathrm{SO}_{4}$ (T5) also promoted beneficial responses by increasing the number of reproductive shoots; however, the $\mathrm{T} 1$, in which $\mathrm{KCl}$ was added to substitute $\mathrm{K}_{2} \mathrm{SO}_{4}$ in the first two sprays, promoted low performance resembling the results of the control treatment (T2), without the use of biostimulant. In this aspect, it is possible to evidence that the $\mathrm{K}$ sources used for shoot maturation have a significant influence on the results. The depressant effect of $\mathrm{KCl}$ on some characteristics of mango tree is due its sensitivity to salinity, especially to the chloride excess of this source (ZUAZO; RAYA; RUIZ, 2003).

The positive effects of applying amino acids in mango cv. Tommy Atkins have already been reported by Mouco et al. (2009) in plants grown under semi-arid conditions. However, in that research, the treatments were applied during the sprouting and fruiting stages, phases subsequent to the ones adopted in the present experiment.

The yeast extract present in the biostimulant sprayed during the shoot maturation promoted beneficial effects for mango crop that can be attributed to its composition rich in nutrients, proteins, B vitamins and natural growth phytohormones, especially cytokinins (ABD ELMOTTY et al., 2010). These results corroborate with Yu-juan et al. (2018), who inferred that mango shoot differentiation is affected by factors such as protein synthesis and processing, gene expression, hormonal balance, synthesis of secondary metabolites, and levels of starch and sucrose.

Regarding the proportion of staminate and monocline flowers, the treatments did not cause significant effect (Table 3), leading to average values of $45.7 \%$ and $54.3 \%$ for monocline and staminate flowers, respectively. These results are in consonance with Sousa, Pigozzo and Viana (2010), who affirmed that there is predominance of staminate flowers in relation to monocline flowers in mango; however, it is below the proportion recorded by Siqueira et al. (2008), which was 1:2 (monocline:staminate) for cv. Tommy Atkins grown in Petrolina-PE.

Mangifera indica $\mathrm{L}$. is classified as a facultative xenogamic species, i.e., it has crossed reproduction that justifies a higher investment in the male function, since the transport of pollen grains among the flowers, generally, leads to losses (SIQUEIRA et al., 2008). Therefore, the presence of staminate flowers represents a positive reproduction strategy.

\section{CONCLUSION}

There is a positive effect of the biostimulant containing amino acids and yeast extract on physiological and reproductive variables during the shoot maturation phase of mango cv. Tommy Atkins grown in tropical semi-arid region.

For shoot maturation of mango cv. Tommy Atkins, three foliar sprays with biostimulant containing amino acids and yeast extract $(10 \mathrm{~mL}$ per plant) and one with $\mathrm{K}_{2} \mathrm{SO}_{4}(3 \%)$, starting at 45 days after paclobutrazol application (T3), can be recommended.

The use of biostimulant containing amino acids and yeast extract during shoot maturation phase alleviates plant abiotic stress.

\section{REFERENCES}

ABD EL-MOTTY, E. Z. et al. Effect of algae extract and yeast application on growth, nutritional status, yield and fruit quality of Keitte mango trees. Agriculture and Biology Journal of North America, 1: 421-429, 2010.

AGROSTAT/MAPA. Estatísticas de Comércio Exterior do Agronegócio Brasileiro/Ministério da Agricultura, Pecuária e Abastecimento. 2018. Exportações Brasileiras 2017. Available in: < http://indicadores.agricultura.gov.br/agrostat/ index.htm >. Access in: 20 feb. 2019.

ALBUQUERQUE, J. A. S.; MEDINA, V. D.; MOUCO, M. A. C. Indução floral. In: GENÚ, P. J. C.; PINTO, C. A. Q. (Eds.). A cultura da mangueira. Brasília, DF: Embrapa Informação Tecnológica, 2002. v. 1, cap. 13, p. 259-276.

ALVARES, C. A. et al. Köppen's climate classification map for Brazil. Meteorologische Zeitschrift, 22: 711-728, 2013.

ARAÚJO, D. O.; MORAES, J. A. A.; CARVALHO, J. L. M. Fatores determinantes na mudança do padrão de produção e consumo da manga no 
mercado nacional. Revista em Agronegócio e Meio Ambiente, 10: 51-73, 2017.

BARBOSA, L. F. S., CAVALCANTE, Í, H. L.; LIMA, A. M. N. L. Desordem fisiológica e produtividade de mangueira cv. Palmer associada à nutrição de boro. Revista Brasileira de Fruticultura, 38: 1-9. 2016.

CAVALCANTE, Í. H. L. et al. A new approach to induce mango shoot maturation in Brazilian semiarid environment. Journal of Applied Botany and Food Quality, 91: 281-286, 2018.

DAVENPORT, T. L. Management of flowering in three tropical and subtropical fruit tree species. HortScience, 38: 1331-1335, 2003.

DAVENPORT, T. L. Pruning strategies to maximize tropical mango production from the time of planting to restoration of old orchards. HortScience, 41: 544548, 2006.

DU JARDIN, P. Plant biostimulants: definition, concept, main categories and regulation. Scientia Horticulturae, 196: 3-14, 2015.

FARIA, L. N. et al. The effects of irrigation management on floral induction of 'Tommy Atkins' mango in Bahia semiarid. Engenharia Agrícola, 36: 387-398, 2016.

FERRAZ, R. L. S. et al. Trocas gasosas e eficiência fotossintética em ecótipos de feijoeiro cultivados no semiárido. Pesquisa Agropecuária Tropical, 42: 181-188, 2012.

FERREIRA, D. F. Sisvar: a computer statistical analysis system. Ciência e Agrotecnologia, 35: 1039-1042, 2011.

FOOD AND AGRICULTURE ORGANIZATION OF THE UNITED NATIONS - FAO. FAOSTAT database Crops. Available in: $<$ http:// faostat.fao.org/site/339/default.aspx $>$. Access in: 20 dec. 2017.

HAMMAD, S. A. R.; ALI, O. A. M. Physiological and biochemical studies on drought tolerance of wheat plants by application of amino acids and yeast extract. Annals of Agricultural Sciences, 59: 133$145,2014$.

HAWKESFORD, $M$. et al. Functions of macronutrients. In: MARSCHNER, P. (Ed.). Mineral nutrition of higher plants. New York: Academic Press, 2012, v. 3, chap. 6, p. 135-189.

LAXMAN, R. H.; ANNAPOORNAMMA, C. J.; BIRADAR, G. Mango. In: RAO, N. K. S.;
SHIVASHANKARA，K. S.; LAXMAN， R. H. (Eds.). Abiotic stress physiology of horticultural crops. New Delhi: Springer, 2016. v. 1, chap. 10, p. 169-181.

LU, P. et al. Photosynthesis and stomatal conductance of five mango cultivars in the seasonally wet-dry tropics of northern Australia. Scientia Horticulturae, 138: 108-119, 2012.

MALAVOLTA, E.; VITTI, G. C.; OLIVEIRA, S. A. Avaliação do estado nutricional das plantas: princípios e aplicações. 2. ed. Piracicaba, SP: POTAFOS, 1997. 319 p.

MOUCO, M. A. C. et al. Amino acids on mango yield and fruit quality at Submédio São Francisco Region, Brazil. Acta Horticulturae, 820: 437-442, 2009.

RAMÍREZ, F.; DAVENPORT, T. Mango (Mangifera indica L.) flowering physiology. Scientia Horticulturae, 126: 65-72, 2010.

RAMÍREZ, F. et al. The stem age required for floral induction of synchronized mango trees in the tropics. HortScience, 45: 1453-1458, 2010.

RYMBAI, H. et al. Diversity in leaf morphology and physiological characteristics among mango (Mangifera indica L.) cultivars popular in different agro-climatic regions of India. Scientia Horticulturae, 176: 189-193, 2014.

SANTOS, M. R. et al. Irrigation deficit strategies on physiological and productive parameters of 'Tommy Atkins' mango. Revista Caatinga, 29: 173-182, 2016.

SANTOS, M. R.; MARTINEZ, M. A.; DONATO, S. L. R. Gas exchanges of 'Tommy Atkins' mango trees under different irrigation treatments. Bioscience Journal, 29: 1141-1153, 2013.

SCHAFFER, B. et al. Ecophysiology. In: LITZ, R.E. (Ed.). The mango botany, production and uses. Wallingford: Center for Agriculture and Bioscience International, 2009. v .2, chap. 6, p. 170-200.

SILVA, A. A. R. et al. Induction of tolerance to salt stress in soursop seedlings using hydrogen peroxide. Comunicata Scientiae, 10: 484-490, 2019.

SILVA, D. J. et al. Nutrição e Adubação. In: GENÚ, P. J. C.; PINTO, C. A. Q. (Eds.). A cultura da mangueira. Brasília, DF: Embrapa Informação Tecnológica, 2002. v. 1, cap. 10, p. 191-222.

SILVA, V. P. R.; CAMPOS, J. H. B. C.; AZEVEDO, P. V. Water-use efficiency and 
evapotranspiration of mango orchard grown in northeastern region of Brazil. Scientia Horticulturae, 120: 467-472, 2009.

SIQUEIRA, K. M. M. et al. Estudo comparativo da polinização de Mangifera indica L. em cultivo convencional e orgânico na região do Vale do Submédio do São Francisco. Revista Brasileira de Fruticultura, 30: 303-310, 2008.

SOUSA, J. H.; PIGOZZO, C. M.; VIANA, B. F. Polinização de manga (Mangifera indica L.Anacardiaceae) variedade Tommy Atkins, no Vale do São Francisco, Bahia. Oecologia Australis, 14: 165-173, 2010.

TAIZ, L. et al. Fisiologia e desenvolvimento vegetal. 6. ed. Porto Alegre, RS: ArtMed, 2017. 888 p.

TIWARI, D. K.; PATEL, V. B.; PANDEY, A. K. Floral induction in mango: physiological, biochemical and molecular basis. International Journal of Chemical Studies, 6: 252-259, 2018.

URBAN, L. et al. Interpreting the decrease in leaf photosynthesis during flowering in mango. Tree Physiology, 28: 1025-1036, 2008.

URBAN, L.; JANNOYER, M. Functioning and role of stomata in mango leaves. Acta Horticulturae, 645: 441-446, 2004.

VIECCELLI, J. C. et al. Photosynthetic response of two mango cultivars submitted to salt stress and infected with Ceratocystis fimbriata. Scientia Agraria, 19: 20-27, 2018.

YAKHIN, O. I. et al. Biostimulants in plant science: a global perspective. Frontiers in Plant Science, 26: 1-42, 2017.

YU-JUAN, T. et al. Transcriptome of Mangifera indica $\mathrm{L}$. in two different flower bud differentiation stages. Journal of Southern Agriculture, 49: 1257 1264, 2018.

ZUAZO, V. H. D.; RAYA, A. M.; RUIZ, J. A. Salt tolerance of mango rootstocks (Mangifera indica L. cv. Osteen). Spanish Journal of Agricultural Research, 1: 67-78, 2003. 